\title{
The Effect of Periogen Solution on Dental Calculus in vitro: A Pilot Study
}

\author{
'Zsolt Rajnics, ${ }^{2}$ Márta Radnai
}

\section{ABSTRACT}

Introduction: Calculus can accommodate teeth and prosthetic restorations when the patient's oral hygiene is poor. Hardened calculus cannot be removed by patients, it needs professional cleaning using ultrasonic scaler or hand instrument. Solutions dissolving and preventing accumulation of dental calculus may help to keep dentures clean. The aim of this investigation was to examine the effect of Periogen on dental calculus in vitro.

Materials and methods: Calculus was collected via scaling from patients during a routine dental checkup. The samples were stored in carbamide peroxide solution (5\%) for 24 hours, then rinsed and stored in distilled water. First, the $\mathrm{Ca}^{2+}$ content of the calculus was determined by photometric method after treating with $\mathrm{cc}$. hydrochloric acid solution for 1 hour. The calculus samples were put in Periogen solution, prepared according to manufacturer's instruction for 16 hours, then crushed and put in Periogen solution with the same concentrate for 4.5 hours. The $\mathrm{Ca}^{2+}$ dissolved from calculus was measured using same photometric method.

Results: Calculus samples contained $26 \mathrm{mg} / 100 \mathrm{mg} \mathrm{Ca}{ }^{2+}$, which is similar to dentin $(27-28 \mathrm{mg} / 100 \mathrm{mg})$ and to enamel (36 mg/100 mg). The $\mathrm{Ca}^{2+}$ dissolved from calculus after treating with cc. hydrochloric acid for 1 hour was considered $100 \%$. $\mathrm{Ca}^{2+}$ dissolution was $1.5 \%$ after 16 hours $(0.09 \% / \mathrm{h})$ and $5.45 \%$ $(1.21 \% / h)$ for the next 4.5 hours after pulverizing the sample. This showed Periogen $\mathrm{Ca}^{2+}$ dissolution was $385 \mu \mathrm{g} / 100 \mathrm{mg}$ after 16 hours direct contact with the material.

Conclusion: The experiment showed that pulverizing the previously hard calculus was done easily after soaking it in Periogen. The ability of Periogen to soften the calculus needs to be further investigated.

Keywords: Calculus, Oral disease, Periodontal, Periogen.

How to cite this article: Rajnics Z, Radnai M. The Effect of Periogen Solution on Dental Calculus in vitro: A Pilot Study. Int J Experiment Dent Sci 2017;6(1):33-34.

Source of support: Nil

Conflict of interest: None

\footnotetext{
${ }^{1}$ Lecturer, ${ }^{2}$ Professor and Chair

1,2Division of Prosthodontics, Faculty of Dentistry, Oral and Maxillofacial Surgery, University of Pécs Medical School, Pécs Baranya, Hungary

Corresponding Author: Zsolt Rajnics, Lecturer, Division of Prosthodontics, Faculty of Dentistry, Oral and Maxillofacial Surgery, University of Pécs Medical School, Pécs, Baranya Hungary, Phone: +003672536000, e-mail: zsolt.rajnics@ gmail.com
}

\section{INTRODUCTION}

Supra- and subgingival calculus is largely responsible for the development and progression of periodontal diseases. ${ }^{1-3}$ It can accommodate not only on tooth surfaces, but also on various prosthetic restorations (either fixed or removable dentures) when the patient's oral hygiene is poor and the mechanical cleaning of restorations is insufficient. ${ }^{4,5}$

Patients are not able to remove hardened calculus; it needs professional cleaning using ultrasonic scaler and/ or hand instruments by dental professionals, as well as regular checkups if the patients' oral condition makes it necessary. ${ }^{1,2}$

Dental education is important in the struggle of achieving a good oral hygiene: Dental professionals have to teach their patients of various teeth and denture cleaning methods, appliances, and materials. Besides the mechanical cleaning appliances (e.g., tooth brushes, denture brushes), chemical solutions dissolving and preventing accumulation of dental calculus may help to keep teeth and dentures clean. ${ }^{6}$

Denture wearer patients usually belong to elder population. Their skills to clean their removable dentures can be insufficient, which leads to accommodation of plaque, stains, food particles, and bacteria on their prosthesis. ${ }^{7-9}$ The presence of bacteria on dentures and thus in the oral cavity may be an important contributing factor for chronic systematic diseases, like chronic obstructive pulmonary disease. ${ }^{10}$

The aim of this investigation was to examine the effect of Periogen solution on dental calculus in vitro.

\section{MATERIALS AND METHODS}

For this pilot study, calculus was collected via scaling from patients during a routine dental checkup at the University of Pécs Medical School dental clinic. Calculus was collected from different teeth (equally from anterior and molar teeth) and from different surfaces of the teeth.

The samples were stored in carbamide peroxide solution (5\%) for 24 hours, then rinsed and stored in distilled water until the experiment.

First the $\mathrm{Ca}^{2+}$ content of the collected calculus was determined by photometric method ${ }^{11}$ after treating with cc. hydrochloric acid solution for 1 hour. The calculus 
Table 1: $\mathrm{Ca}^{2+}$ dissolution in different solutions

\begin{tabular}{lllll}
\hline $\begin{array}{l}\text { Mode of soaking (on room } \\
\text { temperature) }\end{array}$ & Soaking time $(\mathrm{h})$ & & Dissolved Ca & \multicolumn{2}{c}{$\begin{array}{l}\text { Speed of dissolution } \\
(\% / h)\end{array}$} \\
\hline Calculus in one block & 16 & $1.5 \%$ & $385 \mu \mathrm{g} / 100 \mathrm{mg}$ & 0.09 \\
Calculus pulverized & 4.5 & $5.45 \%$ & $1,394 \mu \mathrm{gg} / 100 \mathrm{mg}$ & 1.212 \\
Calculus in one block in cc. HCl & 1 & $100 \%$ & $25,550 \mu \mathrm{g} / 100 \mathrm{mg}$ & 10 \\
\hline
\end{tabular}

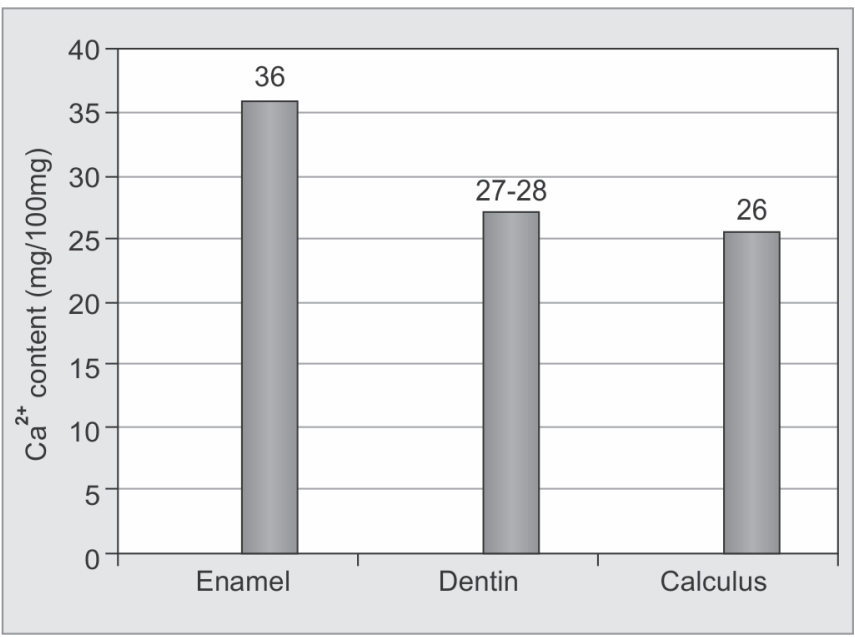

Graph 1: $\mathrm{Ca}^{2+}$ content of tooth structures and calculus

samples were placed in Periogen solution, prepared according to manufacturer's instruction for 16 hours, then crushed and placed in Periogen solution with the same concentrate for 4.5 hours.

$\mathrm{The} \mathrm{Ca}^{2+}$ dissolved from calculus was measured using the same photometric method after the first 16 hours and after another 4.5 hours.

\section{RESULTS}

Calculus samples contained $\mathrm{Ca}^{2+}$, which was similar to dentin (27-28 mg/100 $\mathrm{mg} \mathrm{Ca}^{2+}$ ), and smaller than the $\mathrm{Ca}^{2+}$ content of the enamel (36 mg/100 mg Ca ${ }^{2+}$ ) (Graph 1).

Results of the photometric measurement are shown in Table 1.

The $\mathrm{Ca}^{2+}$ dissolved from calculus after treated with cc. hydrochloric acid for 1 hour was considered $100 \%$. $\mathrm{Ca}^{2+}$ dissolution was $1.5 \%$ after 16 hours $(0.09 \% / \mathrm{h})$ and $5.45 \%$ $(1.21 \% / \mathrm{h})$ for the next 4.5 hours after pulverizing the sample.

Quantitative $\mathrm{Ca}^{2+}$ dissolution from one block calculus was $385 \mu \mathrm{g} / 100 \mathrm{mg}$ after 16 hours and 1,394 $\mu \mathrm{g} / 100 \mathrm{mg}$ after additional 4.5 hours from pulverized calculus with direct contact of Periogen.

\section{CONCLUSION}

$\mathrm{Ca}^{2+}$ dissolution from hardened calculus was achieved by slow rate, but by pulverizing the calculus samples helped to induce the rate of dissolution. The experiment also showed that pulverizing the previously hard calculus was done easily after soaking it in Periogen. The ability of Periogen to soften the calculus needs to be further investigated. Therefore, the solution could help patients in cleaning their removable dentures after overnight soaking in Periogen, making the deposits softer, easier removable by mechanical cleaning devices.

\section{REFERENCES}

1. Jepsen S, Deschner J, Braun A, Schwarz F, Eberhard J. Calculus removal and the prevention of its formation. Periodontol 2000 2011 Feb;55(1):167-188.

2. Roberts-Harry EA, Clerehugh V. Subgingival calculus: where are we now? A comparative review. J Dent 2000 Feb;28(2): 93-102.

3. Saini R. Dental calculus: a strategic review. Int J Dent Health Sci 2014;1(5):788-795.

4. Dula LJ, Ahmedi EF, Lila-Krasniqi ZD, Shala KSh. Clinical evaluation of removable partial dentures on the periodontal health of abutment teeth: a retrospective study. Open Dent J 2015 Mar;9:132-139.

5. Zlatarić DK, Celebić A, Valentić-Peruzović M. The effect of removable partial dentures on periodontal health of abutment and non-abutment teeth. J Periodontol 2002 Feb;73(2): 137-144.

6. Srinivasan M, Gulabani M. A microbiological evaluation of the use of denture cleansers in combination with an oral rinse in complete denture patients. Indian J Dent Res 2010 Jul-Sep;21(3):353-356.

7. Hoad-Reddick G, Grant AA, Griffiths CS. Investigation into the cleanliness of dentures in an elderly population. J Prosthet Dent 1990 Jul;64(1):48-52.

8. Kanli A, Demirel F, Sezgin Y. Oral candidosis, denture cleanliness and hygiene habits in an elderly population. Aging Clin Exp Res 2005 Dec;17(6):502-507.

9. Strajnić L, Dokić M, Vucinić P. Contemporary methods and mobile denture cleansers and theirs significance for older population. Med Pregl 2011 Sep-Oct;64(9-10):497-502.

10. Przybyłowska D, Rubinsztajn R, Chazan R, Swoboda-Kopeć E, Kostrzewa-Janicka J, Mierzwińska-Nastalska E. The prevalence of oral inflammation among denture wearing patients with chronic obstructive pulmonary disease. Adv Exp Med Biol 2015 Mar;858:87-91.

11. Moorehead WR, Biggs HG. 2-Amino-2methyl-1-propanol as the alkalizing agent in an improved continuous-flow cresolphtalein complexone procedure for calcium in serum. Clin Chem 1974 Nov;20(11):1458-1460. 